\title{
GENERAL ELECTIONS IN A MULTIPATIC SYSTEM AND ITS EFFECT ON NATIONAL POLITICAL STABILITY IN HISTORICAL VIEW
}

\author{
Imawan Sugiharto \\ Universitas Pancasakti Tegal Indonesia \\ Email: imawansugiharto57@gmail.com
}

\begin{abstract}
The multiparty system has a major impact on government and society's stability at large, both directly and indirectly. This system has been implemented since 1950, despite experiencing problems and changes in it. In the reform era, Indonesia reused this system based on democratic principles. The method used is normative juridical with a descriptive analysis approach in the perspective of comparative historical politics. The discussion in this study uses a comparative political approach. From this study, it is known that there is a relationship between the multiparty electoral system, the executive-legislative relationship, as well as the broad impact on national political stability in various fields.
\end{abstract}

Keywords: General Election, Multiparty, Political Stability.

\section{A. INTRODUCTION}

In essence, there is no perfect government system because all of them have the unique deficiencies of each of the systems listed in history (Andriyan, 2016). However, until now, democracy is believed to be the best political system capable of leading people to a better future. It avoids people from tyrannical leaders, respects human rights more, freedom of opinion, freedom of thought, provides moral autonomy and guarantees private ownership and human development (Sudarsa, 2018).

General elections are an important element for a democratic country, an important characteristic that must be carried out periodically within an agreed period of time, as the best means of channelling the very principle human rights of citizens (Wiyono, 2009). So the government is obliged to guarantee the implementation of general elections by the principles of people's sovereignty (Hansen, 2008). These human rights are contained in political party institutions. Law Number 2 of 2008 concerning Political Parties defines that Political Parties are national organizations formed by a group of Indonesian citizens voluntarily based on common goals and wills to fight for the political interests of members of society, the nation and the state, and to maintain the integrity of the Unitary State of the Republic of Indonesia (Nirahua, 2009) 
Strengthening the government system through multiparty general elections has been a hot topic since 2004 (Sitompul, 2018). The implementation of simultaneous general elections (legislative and presidential) is considered one way to achieve a multiparty presidential system in Indonesia (Agustiawan, 2017). This system is also considered good because it places the people as the holder of the highest legal control and sovereignty through general elections carried out by political parties (Asmoro, 2009). Political parties have four functions, namely: (1) a means of political communication, (2) a means of political socialization, (3) a means of political recruitment, (4) a political regulator (Miriam, 2000). Parties play a significant role in stating the interests that are sometimes implicit in society. Political parties can best absorb the various interests into written ideas, visions and policies. After that, the ideas and policies are advocated to influence the formulation of state policy (Hanafi, 2016).

In a democratic system, each party is part of the party system applied in a country. in a certain system, parties interact with other parties by applicable regulatory constructs. The party system provides an overview of competition among political parties to gain power in government (Faidi, 2013). The institutionalized party system tends to increase political stability and government effectiveness (Ambardi, 2008). There is an approach commonly known in viewing this party system, which is to see parties as units and as a single unit independent of other units (Swantoro, 2004). During the Reformation period, Indonesia implemented a multi-party system after decades of unfulfilled freedom of expression and association and assembly (Arman, 2018). When reforms provide room for freedom, politicians' desire to establish political parties is channelled. As a learning process, the proliferation of political parties should be seen as a natural phenomenon in a still-developing state society.

General elections have become the mainstay of modern countries. General elections are based on equality, namely that every citizen has the same rights and position in the Government. Therefore every citizen actually has equal sovereignty. This people's power is the source of legitimacy and legality of state power. This, of course, cannot be realized if there is no national stability (Pereira, 2016). General elections involve individual citizens' power and role, including private organizations (Green, 2015). To achieve free, safe, fair and peaceful elections, space and mechanisms for maximum participation must be created, namely the right of citizens to make decisions according to their own will, without coercion from interested parties, because of the idea of democracy to protect citizens' rights. In implementing the freedom to express opinions, the development of national stability needs to 
be developed with several approaches that can build the Indonesian people's collective awareness to defend the State, for example by implementing absolute State Defense Education (Kamungi, 2009).

From the description above, the researcher is interested in looking at the multiparty system in general elections from the perspective of analyzing Indonesia's phenomenon and history and its impact on political stability.

\section{B. METHOD}

The method that the researcher uses in this research is normative juridical with a descriptive analysis approach. Initial research begins with analyzing objective law (legal norms), then analyzing subjective law appropriate according to the researcher's point of view based on a historical point of view and is applied to the present. Researchers use sources of data come from Primary Legal Materials, Secondary Legal Materials and Tertiary Legal Materials. The research method used is a literature study with deductive analysis.

\section{RESULTS AND DISCUSSION}

\section{Multiparty System in Indonesian History}

In its history, Indonesia has practised a multiparty system with various modifications in it (Gene, 1997). In the first general election in 1955 - a milestone in post-independence political life until now it produced five major parties: PNI, Masyumi, NU, PKI, and PSI. The number of 29 parties is quite a lot, plus independent parties participate in enlivening the political party. With a proportional electoral system, it produces a balanced legislative member between Java and Outside Java. The general elections of the 1950s and 1960s were multiparty systems without a majority winner (Liddle, 2006).

However, in the era of parliamentary democracy, there was a high level of competition. Entering the decade from 1970 to 1971, Indonesia still adhered to a simple multiparty system (simple pluralism). At that time, there were nine political parties left from the 1955 general election. An interesting phenomenon in the 1971 general election was Golkar's spectacular victory, which was beyond many people's expectations, although many people considered the result pessimistic (Hamudy, 2019). This happened because of two factors: first, ABRI did not participate in the general election. Second, Golkar has no experience in general elections. However, when the general election was held, the results 
were beyond experts' analysis, Golkar won by more than $63 \%$. The victory indicates that Indonesia is entering a new era, namely the New Order.

In the New Order era, it still used a simple multiparty system, but there was no fierce competition, the reason was that Golkar was a hegemonic party. Experts argue that Indonesia's party system leads to a single-party system (single entry) (Ambardi, 2008). During the reform era, Indonesia returned to implementing a multiparty system after suppressing freedom of expression in Indonesia. When reforms provide space for freedom, there will be lots of new ideas in the Indonesian political arena. As a learning process, the phenomenon of the formation of so many political parties is normal.

In the 1999 general election, using a proportional system with a closed candidate list followed by 48 parties participating in the general election. The number of parties was around 140, but only 48 were verified. With six major parties, namely: (1) PDI-P, (2) Golkar, (3) PPP, (4) PKB, (5) PAN, and (6) PBB. There was no majority in favour of either party. After two general elections following the reformation with a multiparty system, a political evaluation process needs to be carried out on the existing parties and their implementation (Toni, 2006). Namely regarding whether the party's role as a pillar or agent of democracy is more effective in maintaining government stability or vice versa. The 2004 general election was a very historic people's party because Indonesia held a direct general election for the first time. Direct general elections have sovereign Indonesia as the third-best democratic country in the world after America and India (Pardede, 2014).

\section{The Effect of General Elections on National Political Stability}

Simultaneous national elections have major implications in the study of political science (Mboi, 2015). From a political science perspective, multiparty elections have several advantages for the consolidation of democracy in Indonesia, including:

First, multiparty elections aim to create a congruent outcome. This concept makes the presidential system of government possible. The essence of this concept is to combine the implementation of legislative and executive general elections, thereby enabling the creation of a government that is congruent with the election of executive officials (President and Vice President) who receive legislative support so that governance is stable and effective. This created government congruence is assumed to significantly correlate with the stability and effectiveness of government (Marijan, 2019). This is based on the experience of Latin American countries that use a presidential election system with non-concurrent general 
elections that have a fairly broad influence on national stability, which originates from disputes between the elected president and the parliament whose majority of members do not come from a presidential party or coalition selected.

Second, General elections with a multiparty system encourage the creation of policybased coalitions. General elections help create policy-based coalitions because elections also require strong political parties to represent the people's interests and offer alternative policy options that are effective and minimize political pragmatism. Political pragmatism occurs because coalition political parties tend to gain power (office-oriented approach), not because they fight for alternative policies (policy-oriented approach). Based on the Constitutional Court's decision above, the general election will not simultaneously provide oversight to the DPR and the President if positive synergy does not occur. What happened in the two times the presidential election did not produce a long-term coalition that could lead to a simplification of political parties naturally, with multiparty general elections, political parties could no longer coalesce pragmatically (Taufiqurrohman, 2020).

Third, General elections encourage the quality of political parties that are more democratic. The presence of political parties is currently an important prerequisite for modern democratic practice. The literature studies on democracy generally state that free, autonomous, and competitive political parties are important agents for democratic practice. The democratic political system is believed to be able to facilitate the life of political parties that are free, autonomous and competitive, so the democratization of political parties requires the democratization of the political system first, if this is not fulfilled, it will be difficult to emerge political parties as expected (Isnaini, 2020). Learning from history, there is no other choice, except that the Law on Political Parties must determine the basic framework for the candidate pair nomination process's openness. General elections can minimize conflicts between parties or their supporters so that conflicts do not occur throughout the year and conflict management becomes easier.

Fourth, General elections in a multiparty system provide the potential for drastic changes in the presidential threshold, because all political parties that qualify for the election can nominate presidential and vice-presidential candidates. The idea of general elections can overcome dynastic politics, because: (1) If the legislative and executive elections are held simultaneously, everyone (including the incumbent and his relatives) has limited opportunities to run for office. They must choose one of the positions they want to reach: a member of the legislature or an executive position. Both elected and those who are not in an 
equal position in the next five years. (2) The combination of legislative elections and executive elections forces political parties to build coalitions as quickly as possible. They are aware that the electability of the candidates for executive officers that they are promoting, of course, affects the election of candidates for legislative members. Thus, through general elections, it is hoped that it will make an effort to build the quality of a consolidated democracy to simultaneously have a good impact on Indonesian democracy (Akhbar, 2020).

To realize truly democratic elections, the standards as a reference are: (1) The implementation of general elections must provide full opportunities for all political parties to compete freely, honestly and fairly. (2) The implementation of elections has moral integrity and really reflects the will of the people. (3) The implementation of general elections must involve all citizens without discrimination due to people's sovereignty. (4) General elections are carried out employing regulations that support freedom and honesty to achieve an even better democracy. (5) The implementation of general elections should consider the pure instruments of the organizer. (6) General elections should emphasize the manifestation of people's rights in order to create participation in government.

\section{CONCLUSION}

Multiparty elections aimed at creating congruent results. General elections with a multiparty system encourage the creation of policy-based coalitions. General elections encourage a more democratic quality of political parties. General elections in a multiparty system provide the potential for drastic changes in the presidential threshold. It is hoped that this change towards a more positive direction will have a good impact on Indonesia's continuity of democracy to create national welfare and stability in other fields.

\section{REFERENCES}

Agustiawan, M. N. (2017). Pengaruh Multipartai dalam Sistem Presidensil di Indonesia. Jurnal Ilmiah Hukum dan Keadilan, 4(1), 49-61.

Akhbar, A., Miranda, A., Fahrezi, A. N., \& Jannah, M. (2020). Analisis Dampak Sistem Multipartai dalam Implementasi Sistem Pemerintahan Presidensil di Era Jokowi \& Jusuf Kalla. The Journalish: Social and Government, 1(1), 28-32.

Ambardi, K. (2008). The making of the Indonesian multiparty system: A cartelized party system and its origin (Doctoral dissertation, The Ohio State University).

Andriyan, D. N. (2016). Hukum Tata Negara dan Sistem Politik: Kombinasi Presidensial dengan Multipartai di Indonesia. Yogyakarta: Deepublish. 
Arman, Z. (2018). Tinjauan Terhadap Sistem Multi Partai dalam Sistem Pemerintahan Presidensial Di Indonesia Pada Era Reformasi. Jurnal Cahaya Keadilan, 6(1), 23-40.

Asmoro, L. A. (2009). Implikasi Sistem Multipartai dalam Sistem Pemerintahan Presidensiil Di Indonesia (Doctoral Dissertation, Universitas Islam Indonesia).

Faidi, A. (2013). Problematika Legislasi dalam Sistem Pemerintahan Presidensial dengan Sistem Multipartai di Indonesia Pasca Amandemen Undang-Undang Dasar Tahun 1945 (Doctoral dissertation, Universitas Gadjah Mada).

Gene, S. (1997). Menuju Demokrasi Tanpa Kekerasan, Kerangka Konseptual untuk Pembebeasan. Jakarta: Pustaka Sinar Harapan.

Green, P. C., \& Mortensen, P. B. (2015). Avoidance and engagement: Issue competition in multiparty systems. Political Studies, 63(4), 747-764.

Hady, N. (2007). Pelaksanaan Wewenang Mahkamah Konstitusi dalam Menyelesaikan Sengketa Pemilu. Jakarta: Prestasi Pustaka.

Hamudy, M. I. A., \& Rifki, M. S. (2019). Strengthening the Multi-Party Presidential Government in Indonesia. Politik Indonesia: Indonesian Political Science Review, 4(2), 208-232.

Hanafi, R. I. (2016). Menelaah Relasi Eksekutif-Legislatif dalam Sistem Presidensial Multipartai Di Indonesia. Jurnal Penelitian Politik, 12(1), 9.

Hansen, K. M., \& Pedersen, R. T. (2008). Negative campaigning in a multiparty system. Scandinavian Political Studies, 31(4), 408-427.

Isnaini, I. (2020). Koalisi Partai Politik dalam Sistem Pemerintahan Presidensial Indonesia. CIVICUS: Pendidikan-Penelitian-Pengabdian Pendidikan Pancasila dan Kewarganegaraan, 8(1), 93-104.

Kamungi, P. M. (2009). The politics of displacement in multiparty Kenya. Journal of Contemporary African Studies, 27(3), 345-364.

Liddle, R. W., \& Mujani, S. (2006). Indonesia in 2005: A New Multiparty Presidential Democracy. Asian Survey, 46(1), 132-139.

Marijan, K. (2019). Sistem Politik Indonesia: Konsolidasi Demokrasi pasca Orde Baru. Bandung: Kencana.

Mboi, N. (2015). Indonesia: On the Way to Universal Health Care. Health Systems \& Reform, 1(2), 91-97.

Miriam, B. (2000). Pengantar Ilmu Politik. Jakarta: Gramedia.

Nirahua, S. E. M., \& SH, M. (2009). Sistem Multi Partai dalam Pemilihan Umum Di Indonesia. KONSTITUSI Jurnal, 2(1), 84.

Pardede, M. (2014). Implikasi Sistem Pemilihan Umum Indonesia. Jurnal Rechts Vinding: Media Pembinaan Hukum Nasional, 3(1), 85-99.

Sitompul, C. (2018). Konflik Internal Partai Sebagai Salah Satu Penyebab Kompleksitas Sistem Multipartai di Indonesia. Jurnal Legislasi Indonesia, 5(1), 102-129.

Sudarsa, A. G. (2018). Sistem Multipartai di Indonesia. Jurnal Legislasi Indonesia, 5(1), 112. 
Swantoro, F.S. (2004). Meneropong Sistem Kepartaian Indonesia 2020. Jakarta: Soegeng Sarjadi Syndicate.

Pereira, C., Bertholini, F., \& Raile, E. D. (2016). All the President's men and women: coalition management strategies and governing costs in a multiparty presidency. Presidential Studies Quarterly, 46(3), 550-568.

Taufiqurrohman, M. M. (2020). Koalisi Partai Politik dan Implikasinya Terhadap Sistem Presidensial Multipartai di Indonesia. Kertha Semaya: Jurnal Ilmu Hukum, 9(1), 131148.

Toni, A. P. (2006). Mengenal Teori-Teori Politik. Bandung: Nuansa.

Wiyono, S. (2009). Pemilihan Umum Multi Partai Dan Stabilitas Pemerintahan Presidensial Di Indonesia. KONSTITUSI Jurnal, 2(1), 8. 